\title{
BIOGENIC FOSSIL CONCENTRATION IN FLUVIAL SETTINGS: AN EXAMPLE OF A CYNODONT TAPHOCOENOSIS FROM THE MIDDLE TRIASSIC OF SOUTHERN BRAZIL
}

\author{
CRISTINA BERTONI-MACHADO \\ Programa de Pós-graduação em Geociências, UFRGS, Av. Bento Gonçalves, 9500, 91509-900 Porto Alegre, RS, Brazil. \\ cristina.bertoni@ufrgs.br \\ MICHAEL HOLZ \\ Departamento de Paleontologia e Estratigrafia, UFRGS, Av. Bento Gonçalves, 9500, 91509-900 Porto Alegre, RS, Brazil. \\ michael.holz@ufrgs.br
}

\begin{abstract}
Nearby the city of Santa Cruz do Sul (central region of Rio Grande do Sul State in Brazil), an outcrop of the Triassic Santa Maria Formation contains a rather unusual fossil occurrence consisting of a concentration of disarticulated therapsid skeletons dominated by herbivorous and carnivorous cynodonts. Noncynodont remains are restricted to a single specimen of Rhadinosuchidae (Archosauriformes: Proterochampsia). The taphocoenosis is characterized by the chaotic accumulation of tens of isolated fossil bones within a block of mudrock $10 \mathrm{~m}$ wide and $20 \mathrm{~m}$ long, and approximately $5 \mathrm{~m}$ thick. The site lies within an approximately $30 \mathrm{~m}$ thick succession of red mudstone displaying horizons of rhizoliths and carbonate nodules which are interpreted as palaeopedogenic carbonate precipitation in alluvium on a semi arid floodplain. Preservation of the fossil bones at this site is unusually good. Microstructure of the bones shows external and internal precipitation of calcite and quartz in the vessel cavities and pores in the bone matrix indicating that they were initially filled by calcite, and than partially replaced by quartz. These features combined with the presence of calcareous rhizoliths and carbonate nodules, suggest that the bones were accumulated on a playa lake margin with the position of the shoreline being controlled by the groundwater table movements between dry and wet seasons. The taphocoenosis shows a predominance of disarticulated and disassociated skulls and mandibles. Commonly large and very small bones occur side-by-side with no preferred orientation. This taphonomic style suggests a biogenic agent of concentration of the bones by selective predation.
\end{abstract}

Key words: Biogenic concentration, floodplain, Triassic, vertebrate taphonomy.

RESUMO - Perto da cidade de Santa Cruz do Sul (região central do Rio Grande do Sul, Brasil), um afloramento Triássico da Formação Santa Maria apresenta uma assembléia fóssil bastante incomum, consistindo de uma concentração de restos esqueletais de terápsidos desarticulados, com predomínio de ossos de cinodontes herbívoros e carnívoros. Apenas um espécime de Rhadinosuchidae (Archosauriformes: Proterochampsia) foi encontrado. A tafocenose é caracterizada por uma acumulação caótica dos ossos isolados, em um nível pelítico de $10 \mathrm{~m}$ de largura e $20 \mathrm{~m}$ de comprimento e aproximadamente $5 \mathrm{~m}$ de altura. $\mathrm{O}$ afloramento encontra-se numa sucessão de aproximadamente $30 \mathrm{~m}$, cujos pelitos vermelhos apresentam horizontes com presença de rizólitos e nódulos de carbonato de cálcio, que são interpretados como precipitações de carbonato pedogênico numa planície semiárida. A preservação dos fósseis neste afloramento raramente é boa. A microestrutura óssea apresenta precipitações externas e internas de calcita e quartzo nas cavidades e poros, indicando que eles foram inicialmente preenchidos por calcita e posteriormente, esta foi substituída por quartzo. Isto, associado à presença de nódulos carbonáticos e rizólitos sugere que os ossos foram acumulados nas margens de um lago efêmero, cujo controle se deu por flutuações no lençol freático em estações úmidas e secas. A tafocenose mostra um predomínio de crânios e mandíbulas desarticulados e não-associados e comumente ossos grandes e pequenos ocorrem lado a lado, sem uma orientação preferencial. Este modo tafonômico de ocorrência sugere um agente biogênico de concentração, que selecionou os ossos por predação seletiva.

Palavras-chave: Concentração biogênica, planície, Triássico, tafonomia de vertebrados. 


\section{INTRODUCTION}

Bone concentrations are relatively common in the fossil record. However, the genesis of such concentrations is often poorly researched or not considered at all. Taphonomic processes such as scavenging, predation, trampling, fluvial transportation and re-working of organic remains all leave their taphonomic signature on the fossil assemblage (Turnbull \& Martill, 1988). Thus, to fully understand the palaeoecological significance of the fossil assemblage such events must be adequately investigated as part of a detailed taphonomic analysis. This study concerns a fossil bone accumulation in the Triassic portion of the Paraná Basin of southern Brazil. This very large intracratonic basin of southwestern Gondwana, was intermittently active from the Late Ordovician to early Cretaceous. It is NE-SW orientated and is approximately $1,750 \mathrm{~km}$ long and $900 \mathrm{~km}$ wide, covering an area of 1,700,000 km² (Figure 1A).

The basin formed after the Brasiliano Cycle (the Brazilian tectonic equivalent for the coming together of Gondwana during Proterozoic) with plutonic events (610-580 m.y.) and subsequent cooling and thermal subsidence in CambroOrdovician times (500-450 m.y.). During the middle Mesozoic,

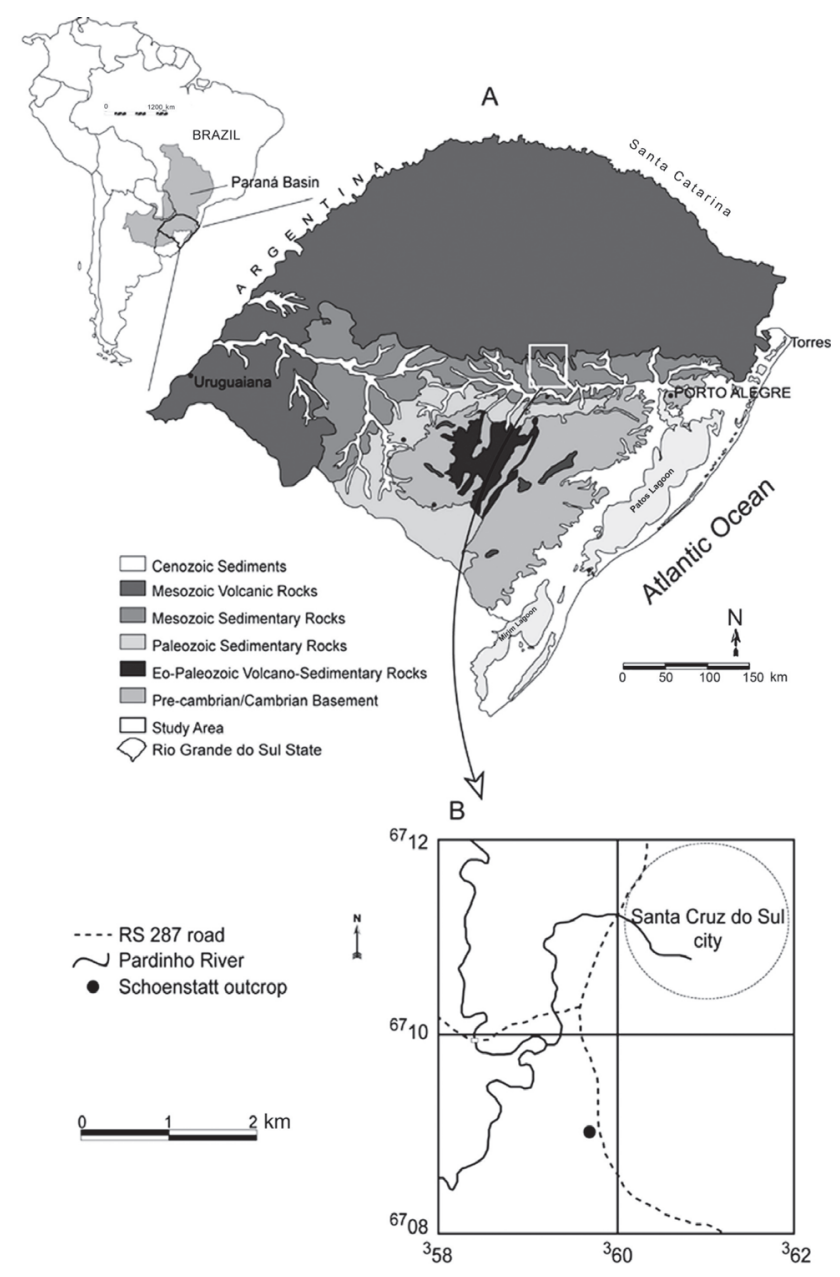

Figure 1. Location map of the studied outcrop in the Paraná Basin and in the central region of Rio Grande do Sul State. preceding the opening of the South Atlantic, the Paraná Basin underwent tectonic reorganization due to the paroxysm of the Sierra de la Ventana-Cape Fold Belt orogen. This tectonism resulted in uplift of large areas of the former Paraná Basin, leading to intraplate rifting and the formation of several small extensional basins (Zerfass et al., 2003, 2004). Our study focuses on the red-bed type sediments (Figure 2) that accumulated in one of these restricted extensional basins during the Middle Triassic. They form part of the Santa Maria Formation (sensu Andreis et al., 1980) that crops out in Rio Grande do Sul, the southernmost state of Brazil (Figure 1B). This formation has two members, called Passos das Tropas and Alemoa. The conglomerates of the Passo das Tropas Member have not yielded any fossil vertebrates to date.

The Alemoa Member contains the study site and is characterized by large amounts of tabular, massive or thinly laminated red coloured mudstones with calcitic palaeosol horizons (i.e., rhizoliths and carbonate nodules) and some interfingering sandstone lenses. Fonseca (1999) attributes these deposits to an anastomosed fluvial system, where the mudstones (associated with calcrete nodules) were deposited on the floodplain while the sandstone lenses represent inchannel deposits.

Middle Triassic tetrapod faunas mainly comprise archosaurs, dicynodonts, cynodonts, rhynchosaurs, besides less well represented groups like procolophonids and sphenodontids (e.g., Schultz, 1990; Rubert \& Schultz, 2004).

Most of the paleontological record of Rio Grande do Sul Triassic rocks shows some kind of biostratinomic or diagenetic modification, including hydraulic selection of bones, scavenger action and diagenetic "explosion" and recementation (e.g., Holz \& Barberena, 1994; Holz \& Schultz, 1998; Holz \& Souto-Ribeiro, 2000).

During taxonomic analysis, Abdala et al. (2001) noted that the taphocoenosis of a section located at Santa Cruz do Sul city, in the central region of Rio Grande do Sul State, is very peculiar because of the large number of cynodont skulls and lower jaws found in these massive red mudstones. We have investigated this peculiar location, known as the Schoenstatt outcrop, and have confirmed the findings of Abdala et al. (2001) that unlike other fossiliferous outcrops in the Triassic succession in Rio Grande do Sul State, the Schoenstatt outcrop is characterized by a bone accumulation of low taxonomic variability with highly disarticulated and selective preservation.

The traditional taphonomic models (e.g., Holz \& Barberena, 1994) for the Triassic succession do not explain the taphonomic signature of this particular outcrop, thus a detailed taphonomic study was developed based on palaeoecological and palaeoenvironmental reconstruction (Bandyopadhyay et al., 2002) in order to understand the sequence of events that led to this unusual fossil occurrence. Smith \& Swart (2002) observed this kind of fossil concentration at the Omingonde Formation (Karoo Supergroup, Namibia). They recognized three different taphonomic assemblages. Schoenstatt taphocoenosis seems to be very similar to the assemblage found in loessic plains, 
in which isolated skulls without lower jaws and isolated postcranial bones of different cynodonts taxa were collected.

\section{SEDIMENTOLOGY AND STRATIGRAPHY OF SCHOENSTATT OUTCROP}

The Schoenstatt outcrop is located alongside road RS 287 near Santa Cruz do Sul city (UTM (22) 359767 E, 6709062 $\mathrm{N}$ ), about $150 \mathrm{~km}$ from Porto Alegre (capital of Rio Grande do Sul State, Figure 1). It displays approximately $20 \mathrm{~m}$ of mudstone (Alemoa Member, Santa Maria Formation, sensu Andreis et al., 1980) topped by nearly $15 \mathrm{~m}$ of fine to very fine sandstone (Caturrita Formation sensu Andreis et al., 1980).

The mudstone is either massive or has millimetre scale, intermittent horizontal lamination. Rhizoliths, some with fibroradial calcite mineralization and calcium carbonate filled fractures are common. The uneven distribution of tetrapod fossils in this unit is clearly anomalous. The basal $15 \mathrm{~m}$ of the section are almost barren of fossils, whereas the upper part of the succession (between 15 and $20 \mathrm{~m}$, Figure 3) numerous vertebrate fossils and coprolites are found in lateral association with carbonate nodules. Immediately above the bone concentration, a horizon of carbonate nodules occurs in association with calcite-filled fractures.

The sandstone dominated Caturrita Formation (sensu Andreis et al., 1980) at the top of the section is apparently barren of fossils. It is composed of four fine-grained sandstone bodies structured with horizontal lamination and trough cross-bedding and very fine-grained sandstones displaying climbing ripple cross-lamination, rhizoliths and small carbonate nodules ( $3 \mathrm{~cm}$ diameter).

The Schoenstatt section is interpreted as a facies association of channel and floodplain deposits. The upper sandstone is interpreted as an in-channel deposit of a low sinuosity river with flanking semi arid and sparsely vegetated floodplain represented by the mudrock dominated interchannel sequences.

\section{Tetrapod paleofauna}

Abdala et al. (2001) were the first to describe the fauna collected at the Schoenstatt outcrop, where more than 50 bone elements of cynodonts were observed, including skulls, lower jaws and postcranium elements. They were classified as herbivorous Traversodontids and one carnivorous Chiniquodontid based on features of the postcanines.

Although Abdala et al. (2001) found only cynodonts at the Schoenstatt outcrop, Machado \& Kischlat (2003) collected from the same locality several disarticulated bones of the skull, a partial lower jaw and a few elements from the hind limbs of a proterochampsid archosaur (Figure 4).

\section{TAPHONOMIC DATA}

The taphocoenosis occur in the form of loosely packed, scattered bone elements forming a $5 \mathrm{~m}$ thick level with approximately $10 \mathrm{~m}$ lateral extension at the outcrop, as depicted by the schematic block diagram in Figure 3.

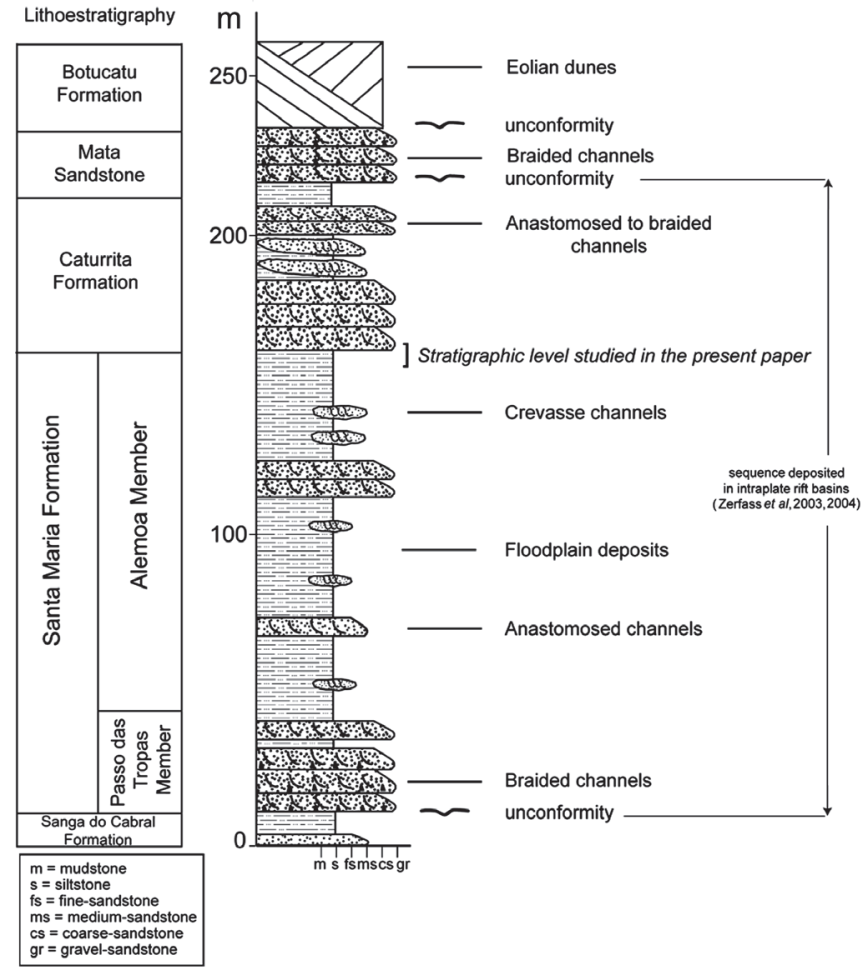

Figure 2. Composite stratigraphic profile of the Triassic succession in the study area, showing main environmental facies and the lithostratigraphic units. The studied outcrop represents the passage from the Santa Maria to the Caturrita Formation (modified from Holz \& Scherer, 2000)

Data on fossil distribution and taphonomic signatures were obtained by detailed stratigraphic description of outcrops and acquiring taphonomic data such as fossil orientation, disarticulation, preservation and association with fossil remains.

All collected specimen were identified and registered in the fossil bone data bank of the vertebrate paleontology laboratory of the Universidade Federal do Rio Grande do Sul (data bank UFRGS PV-T). From analysis of these fossils and the field data some observations can be made.

There is a predominance of skulls and lower jaws and a disparity in the number of preserved pelvic girdles and shoulder girdles (Table 1).

Carbonate concretions (Figure 5) are present in several stratigraphic levels within the studied profile, but they are more concentrated in association with the bone accumulations and many of the bones are enveloped in a carbonate crust. X-ray diffractometry and Scanning Electron Microscopy of the concretionary material that occurs on the external surface (Figure $6 \mathrm{~A}$ ) of the bones as well as the internal permineralization shows it to consist mainly of calcite, as is usually found in other diagenetically affected bones from the Santa Maria Formation (Andreis et al., 1980; Holz \& Schultz, 1998). However, the analysis did indicate the presence of silica, especially in the internal pores of the bones (Reichel et al., 2005). The association of quartz and calcite suggests that this area has a distinct mode of preservation, where silica (quartz) filled the internal porous structure and Volkmann and Haversian canals of the bones before the bone material itself was replaced by calcite (Figures 6B, C). 

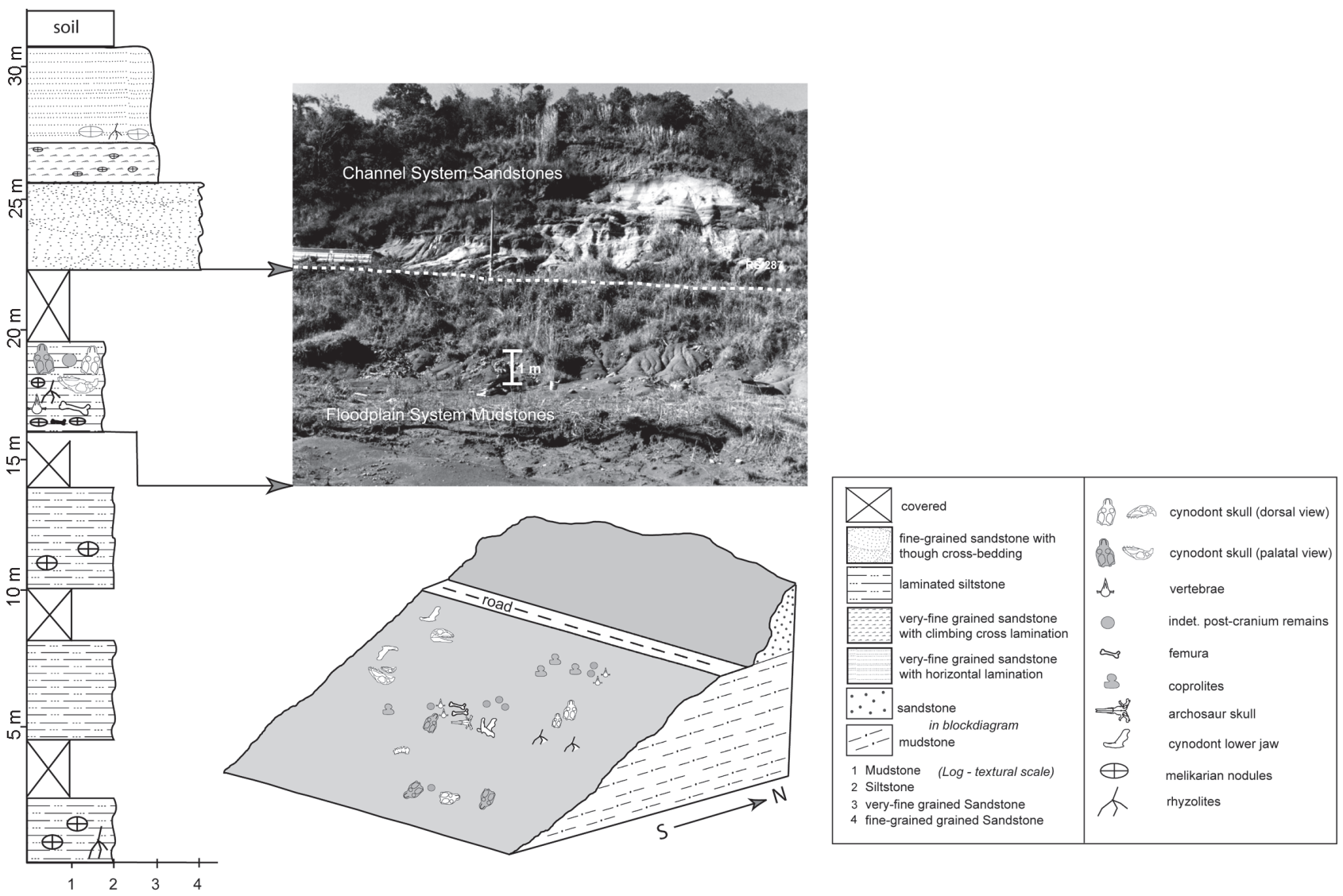

Figure 3. Stratigraphic profile of the studied outcrop. Note the sharp contact between the mudstone facies representing floodplain setting and the overlying channel sandstone, where no fossil bones were found. The fossils were found in a stratigraphic level close to that contact (fossil content in Table 1). The schematic block diagram illustrates the relative position of the analyzed fossil bones, evidencing the loosely packed, scattered mode of occurrence of the bone elements. Bones of completely different sizes and densities, such as skulls, lower jaws mixed with fragments of ribs, sequences and isolated vertebrae and teeth (shown in Figure 8), were preserved in the fossil bearing succession.

Coprolites occur at the same stratigraphic level as the bone accumulation. They consist only of external molds secondarily infilled by calcite (Figure 7) and because no internal structures are preserved, they have not yet been accurately identified. The faunal composition of the taphocoenosis is clearly biased towards herbivorous cynodonts. The taphocoenosis consists of four types of herbivorous cynodonts, one carnivorous cynodont and one proterochampsid archosaur. Despite the taxonomic variety, the low diversity of bone elements is noticeable, as well as the rare occurrence of articulated skeletal segments.

Many different complete or fragmented lower jaws and skulls, teeth (Figure 8), limb bones, vertebrae and other indeterminate fragments were identified, but only one articulated vertebral section and one pelvic girdle was found. Two of the four preserved femora belong to herbivorous cynodonts, which were huge in comparison to the archosaur found in the taphocoenosis (Table 1).

\section{DISCUSSION}

Taphocoenosis of disarticulated and fragmented bones in a floodplain setting can result from selective transportation by water or by biotic factors. The preservation of bones with completely different sizes and densities within the same fossiliferous level precludes the analysis of the so-called transportability groups (sensu Voorhies, 1969) evidence for

Table 1. Fossil content of the stratigraphic level shown in Figure 3 . In the number of specimens and approximate size columns, regular numbers refer to cynodont bones; numbers in parenthesis refer to archosaur bones.

\begin{tabular}{l|c|c}
\hline Bone & $\begin{array}{c}\text { Number of } \\
\text { specimens }\end{array}$ & $\begin{array}{c}\text { Approximate } \\
\text { size }\end{array}$ \\
\hline Skull & $11(1)$ & $5-30 \mathrm{~cm}(10 \mathrm{~cm})$ \\
Lower Jaw & $12(1)$ & $5-30 \mathrm{~cm}(8 \mathrm{~cm})$ \\
Femur & $2(2)$ & $10-20 \mathrm{~cm}(10 \mathrm{~cm})$ \\
Pelvic girdle & 1 & $10 \mathrm{~cm}$ \\
Ischium & 1 & $5 \mathrm{~cm}$ \\
llium & 1 & $5 \mathrm{~cm}$ \\
Tibia & 1 & $10 \mathrm{~cm}$ \\
Humerus & $1(1)$ & $10 \mathrm{~cm}(5 \mathrm{~cm})$ \\
Scapulacoracoid & 1 & $3 \mathrm{~cm}$ \\
Radio & 2 & $3 \mathrm{~cm}$ \\
Ulna & 2 & $2 \mathrm{~cm}$ \\
Articulated vertebrae & 5 & $10 \mathrm{~cm}$ \\
Isolated vertebrae & $5(1)$ & $2-3 \mathrm{~cm}(1 \mathrm{~cm})$ \\
Indeterminate fragments & 8 & Very variable \\
\hline
\end{tabular}


hydraulic transportation and sorting. In addition, there is no preferential orientation of the bones, indicating that there was no competent unidirectional flow involved in the accumulation of these bone elements. The fossil-bearing mudstone is relatively homogeneous throughout the studied section, without development of sandstone lenses, indicating slow settling of suspended sediment within a low energy environment at the bottom of a standing water body. Thus, there is no evidence for running water as an agent for the bone concentration, and the presence of fossils has to be explained by other factors than hydraulic transportation, such as biogenic concentration.

The presence of a semi-aquatic proterochampsid archosaur supports biogenic concentration as the key agent of bone accumulation for this fossil assemblage. Bonaparte (1971) and more recently Arcucci (1990) and Sill (1995) suggested an aquatic habit for this archosaur group due to adaptations such as a long rostrum, flattened skull and the type of tooth insertion in the lower jaw. The protochampsid remains in the bone accumulation suggests the proximity of a relatively permanent body of water. This archosaur is
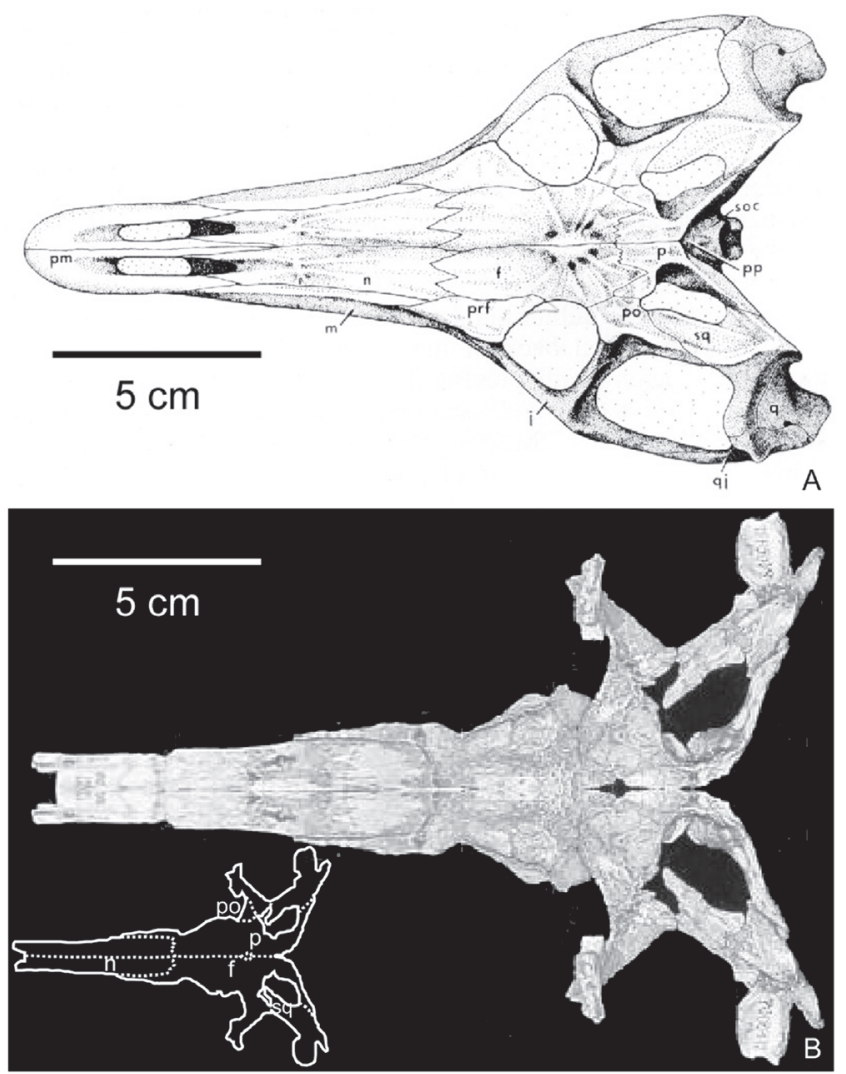

Figure 4. The presence of a proterochampsidae archosaur is a key factor for the interpretation of the fossil assemblage studied in this paper, because this archosaur group had an aquatic habit, as indicated by adaptations such as a long rostrum, flattened skull and the type of teeth insertion in the lower jaw. This kind of archosaur was capable of preying on small animals. A, reconstruction of a typical long snouted proterochampsidae (from Romer, 1971); B, reconstruction of the specimen found at the outcrop, based on the left half of the skull (best preserved portion). Abbreviations: pm, premaxilla; $\mathbf{n}$, nasal; $\mathbf{m}$, maxilla; $\mathbf{f}$, frontal; prf, prefrontal; j, jugal; qj, quadratojugal; q, quadrate; sq, squamosal; po, postorbital; p, parietal; pp, postparietal

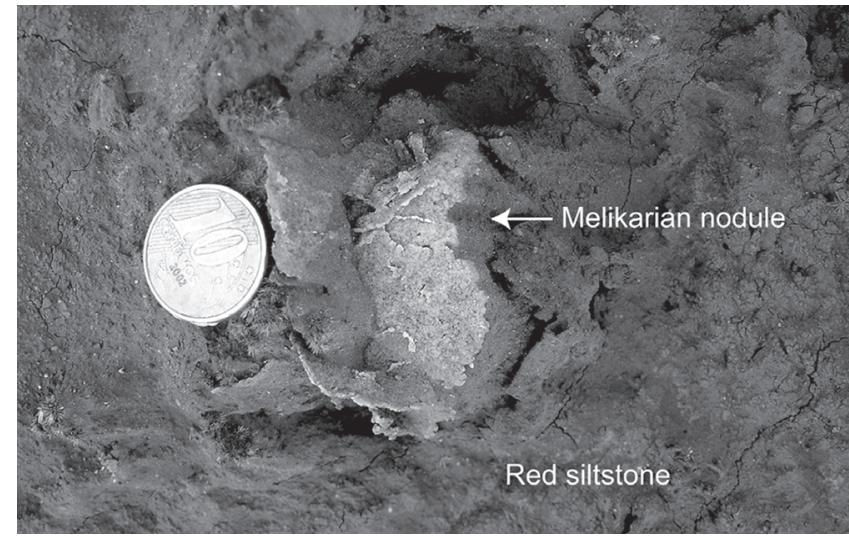

Figure 5. Example of a carbonate nodule, typical concretional feature of the outcrop. This kind of concretion is suggestive of oscillations of the phreatic level. With higher positions of the phreatic level, plant and animal colonization led to the formation of porosity of the soil profile, where the nodules were formed. Scale (coin) = $2 \mathrm{~cm}$ in diameter.

comparable to other Neomesozoic crocodilians which actively preyed on smaller animals such as the herbivorous cynodonts.

In addition, isolated teeth were found lying on top of a cynodont skull (Figure 9A) and other have a very irregular stacking pattern, herein called a chaotic mode of preservation (Figure 9B). These characteristics also strengthens the hypothesis of biogenic concentration of this assemblage, because running water could not stack the bones in that way, hence, this mode of accumulation is very likely to be the result of biogenic activity.

Another factor that corroborates the hypothesis of biogenic concentration by predators/scavengers is the presence of coprolites, because these are characteristic of areas with intense predatory activity (Behrensmeyer, 1991) and is an indicative of animal-plant or animal-animal interaction (Behrensmeyer \& Hook, 1992). The analyzed material exhibits surface characteristics caused by extrusion muscles, but do not present adherence of organic debris. Souto (2001) found the same features in coprolites of other Triassic locations in Rio Grande do Sul State. The fact that these coprolites are fossilized as external moulds suggests similar conditions to those causing the non-preservation of plant material in that outcrop.

The calcareous concretions occur isolated and in association with the fossils, more densely in patches or lenses. This pattern of areal distribution of the concretions is typical of marginal pond environments (Hubert, 1978).

The presence and amount of carbonate nodules varies within the geological section, indicating vertical oscillation of the groundwater table (phreatic level). At higher positions, plant and animal colonization led to the formation of porosity of the soil profile. Cementation in the vadose zone is frequently associated with rhyzoliths, which record the orientation and position of former root systems (Beckner \& Mosley, 1998).

At a later stage, this porous zone is filled with carbonate, recording the marginal zone of the ponds formed when the phreatic level intersects the floodplain surface (da Rosa et al., 2003). At the base of the mudstone succession of the 
Schoenstatt outcrop, the phreatic level was low as suggested by the rare occurrence of concretions, while at the fossiliferous level abundance of concretions may indicate that the phreatic level was appearing at the surface, forming an ephemeral lake. In addition, the presence of rhyzolithes indicate paleosols (Klappa, 1980), showing that this area was wet enough to develop vegetation.

Caliche horizons found within the mudstones and sandstones of the fluvial systems are the result of progressive soil calcification which is characteristic of arid or semi-arid climates, such as those prevailing during the Middle Triassic (Holz \& Scherer, 2000). The presence of caliche concretions within the floodplain deposits suggests deposition under a hot climate with alternating wet and dry seasons (Pierini et al., 2005) forming ephemeral water bodies on the floodplain. During periods of restricted rainfall, any standing water body would be quickly occupied by the vertebrate groups that lived in the area

\section{Origin of the taphocoenosis}

The sedimentological and taphonomic data suggest that the Schoenstatt outcrop area was an oasis on a semi-arid floodplain, since vertebrate remains generally are rare in distal floodplain deposits and, when they occur, they are preserved as disarticulated or isolated postcranium elements, such as vertebrae and ribs (Smith, 1980, 1993).

Since the fossiliferous association in the study area is composed of $90 \%$ herbivorous and carnivorous cynodonts and there is no evidence of hydraulic transport, we consider that the composition of this taphocoenosis biased and does not accurately reflect the composition of the fauna that lived in the region at that time. The taphonomic pattern displayed by the Schoenstatt outcrop leads us to the conclusion that this bias is caused by biogenic concentration.

Wood et al. (1988), Dominguez-Rodrigo (1998), Hungerbühler (1998) and recently Sanders et al. (2003) observed floodplain

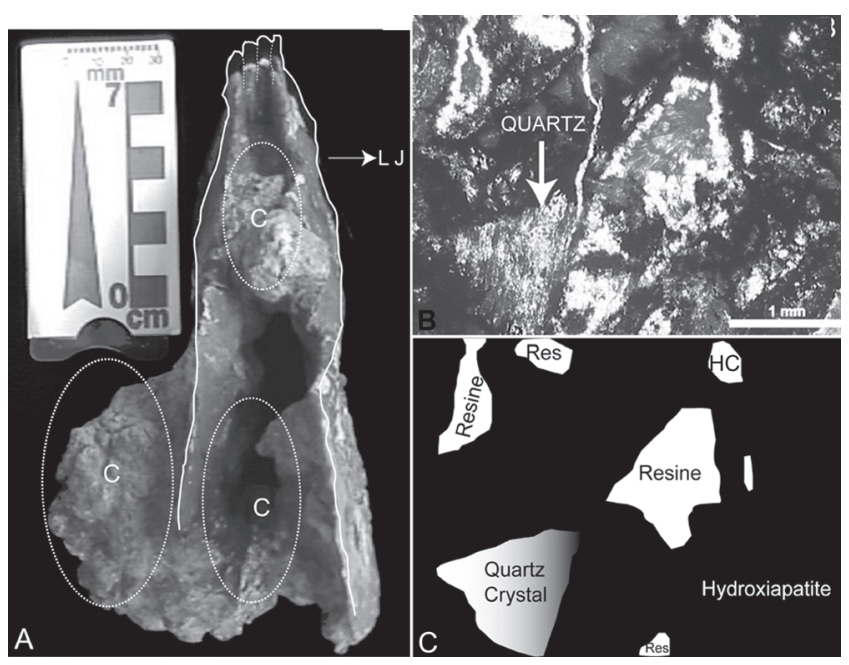

Figure 6. The fossils recovered from the study outcrop show both external and internal concretionary mineralization. A, a cynodont's lower jaw with external calcareous mineralization; B, SEM analysis of a fragment of cynodont rib with crystallization of silica in the Haversian canals; C, a schematic drawing of B. Abbreviations: C, external concretion; HC, Haversian canal; LJ, lower jaw.

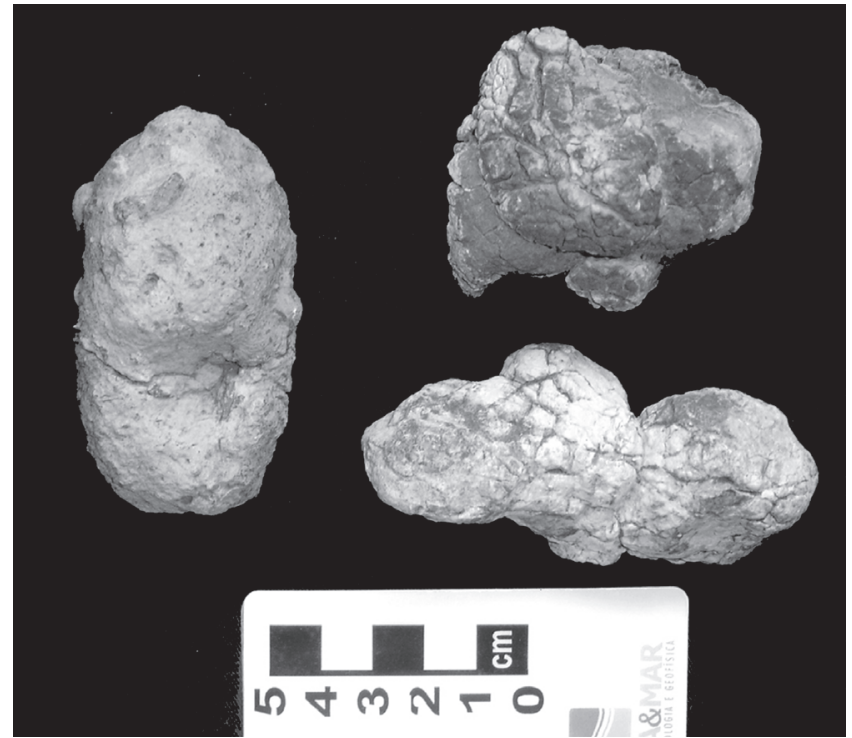

Figure 7. Carbonate casts of coprolites were frequently found in the succession indicating significant biogenic activity in the palaeoenvironment.

sediments with fossiliferous concentration strongly biased towards preservation of skulls and lower jaws, besides an uneven relation between the number of preserved scapular and pelvic girdles, and association of bone remains from different Voorhies groups. These studies indicate that this kind of taphocoenosis is formed as a result of predator/scavenger action. Skulls and lower jaws represent bones with relatively low nutritional value and therefore are usually discarded by predators (Behrensmeyer, 1991), hence they accumulate and concentrate in the floodplain. Behrensmeyer \& Boaz (1980) state that predation may result in concentration of carcasses in habitats like swamps, ponds and waterholes, where scavengers and predators may have dragged dead animals away from the habitats in which they lived. When lower jaws are broken posterior to the symphisis, this may indicate predator action, because modern hyenas are known to break these bones to access the tongue (Behrensmeyer \& Boaz, 1980).

In the case of the Schoenstatt taphocoenosis, carnivorous cynodonts and archosaurs were probably responsible for bone concentration, although direct evidence of necrophagy or predation (e.g., tooth marks) have not been recorded. Mechanical removal of the caliche crust reveals a highly crazed bone surface, hence precluding accurate observation of tiny structures such as tooth marks. A similar situation is described by Smith (1980) studying several outcrops from the Beaufort Formation (South Africa), where predation/necrophagy is interpreted to be the cause for the observed preservational bias of the taphocoenosis, in spite of the lack of direct evidence. Njau \& Blumenschine (2006) point out that predators, such as the proterochampsid archosaur of the Schoenestatt taphocoenosis, lived in aquatic settings. Normally, they do not transport prey over long distances and usually consume prey in the water, a short distance from the kill site, typically on the shoreline. Njau \& Blumenschine (2006) suggest that mammalian carnivores gnaw and break bones to various degrees in order to access marrow, grease and brain tissue. Tooth-marking is inflicted during defleshing, gnawing, 
and fragmentation. In contrast, crocodilians access these nutrients by producing carcass segments, some of which can be swallowed whole. Those parts that cannot be reduced in size sufficiently may come to bear tooth marks and other bone damage before being abandoned. The carcass parts that escape consumption are discarded either complete or broken and allowed to sink to the bottom of the pond. The discarded fragments are referred to by Davidson \& Solomon (1990) as "flown-off" pieces and result in scattered and isolated fossil bone accumulations with little or no evidence of gnawing and chewing, a pattern very similar to the fossil record at the Schoenstatt outcrop.

Rogers \& Broughton (2001) define three hypothetical agents of biogenic selection of the bone remains, based on the difficulty of disarticulation and transport of the selected part (i) unselective: the hunter usually transports the entire preyed animal; (ii) more selective: the hunter usually discards parts of low use before transporting the carcass; (iii) most selective: the hunter usually transports parts of highest use only. Based on this classification, we suggest that the Schoenstatt taphocoenosis was caused by most selective action, because skulls, lower jaws, tooth and vertebral elements were preferentially preserved and all considered elements with low nutritional value.

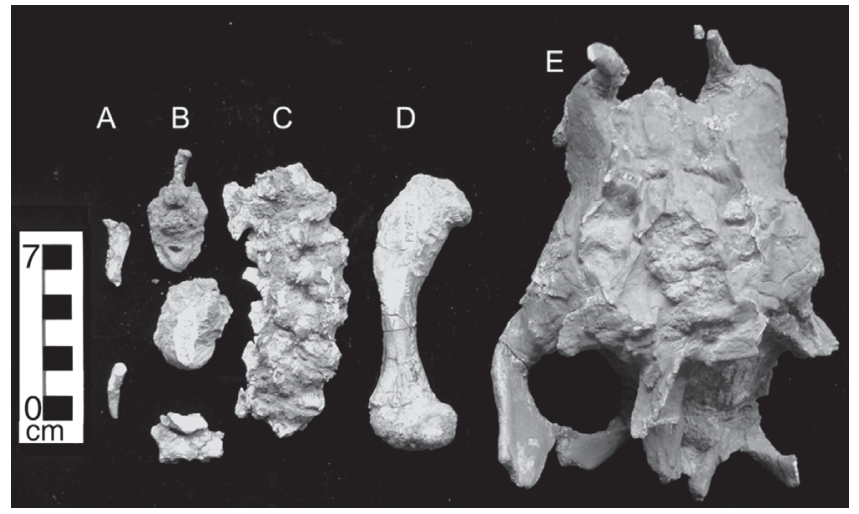

Figure 8. The fossil.bearing strata contains bones of very different sizes and shapes, hence precluding selective transportation. A, cynodont teeth; B, isolated vertebrae; C, articulated cervical vertebrae D, cynodont femur; E, cynodont skull in ventral view.

\section{Taphonomic model}

During deposition of the Schoenstatt strata a sequence of biogenic, sedimentary and climatic events occurred leading to the preservation of a biogenically concentrated taphocoenosis
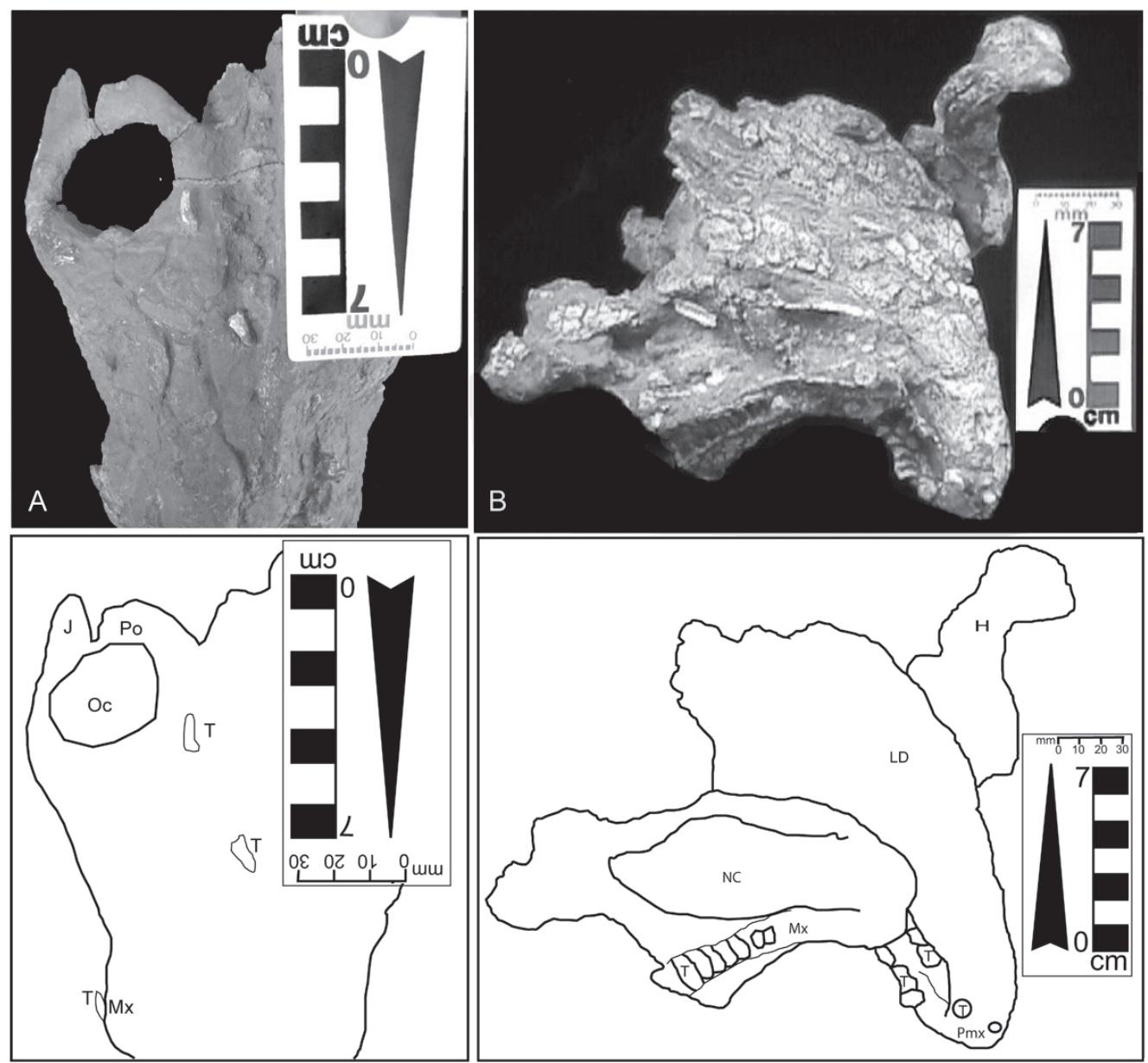

Figure 9. Features of the fossils found at the outcrop: A, teeth preserved at the roof top of the skull; $\mathbf{B}$, anterior fragment of a skull in dorsal view, with a right forelimb composed by a humerus, ulna and a radius attached. This kind of preservational features precludes hydraulic sorting and strengthens the hypothesis of biogenic concentration of this assemblage. Abbreviations: Oc, orbital cavity; Po, postorbital; J, jugal; H, humerus; LD, left dentary; NC, nasal cavity; Mx, maxilla; T, tooth; Pmx, premaxilla. 
which was diagenetically overprinted with silica and calcitic cements (Reichel et al., 2005). The taphonomic model suggests that the site of accumulation by biotic agents was controlled by the migration of pond margins which were in turn controlled by oscillations of the groundwater table (Figure 10).

The paleofauna encountered at the outcrop, such as the carnivorous and herbivorous cynodonts and the archosaur, would have lived in and around ephemeral lakes or ponds on the floodplain. During the day-by-day situation, the water bodies were sustained by the phreatic level controlled by river channels. Under those conditions, some vegetation was developed at the lake margins, as indicated by the presence of rhyzoliths. This lush vegetation would have attracted groups of herbivorous cynodonts and their predators.

During periods of drought, the water volume of the river channels and the phreatic level were low, drying the ephemeral lake. Sheet flood sedimentation during subsequent overbank flow and rainstorms would effectively create a chaotic mélange of isolated bones that were left on the lake margin and bury them in the same event.

With the remains buried and the return of a high phreatic level, the process of pedogenis calcium carbonate deposition would have begun. The calcium carbonate carried by water that rose up from the phreatic level by capillarity filled the

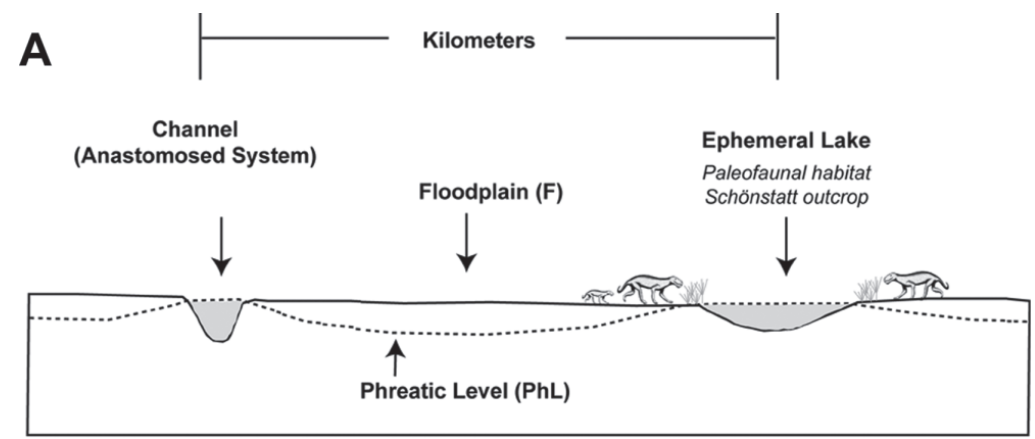

B
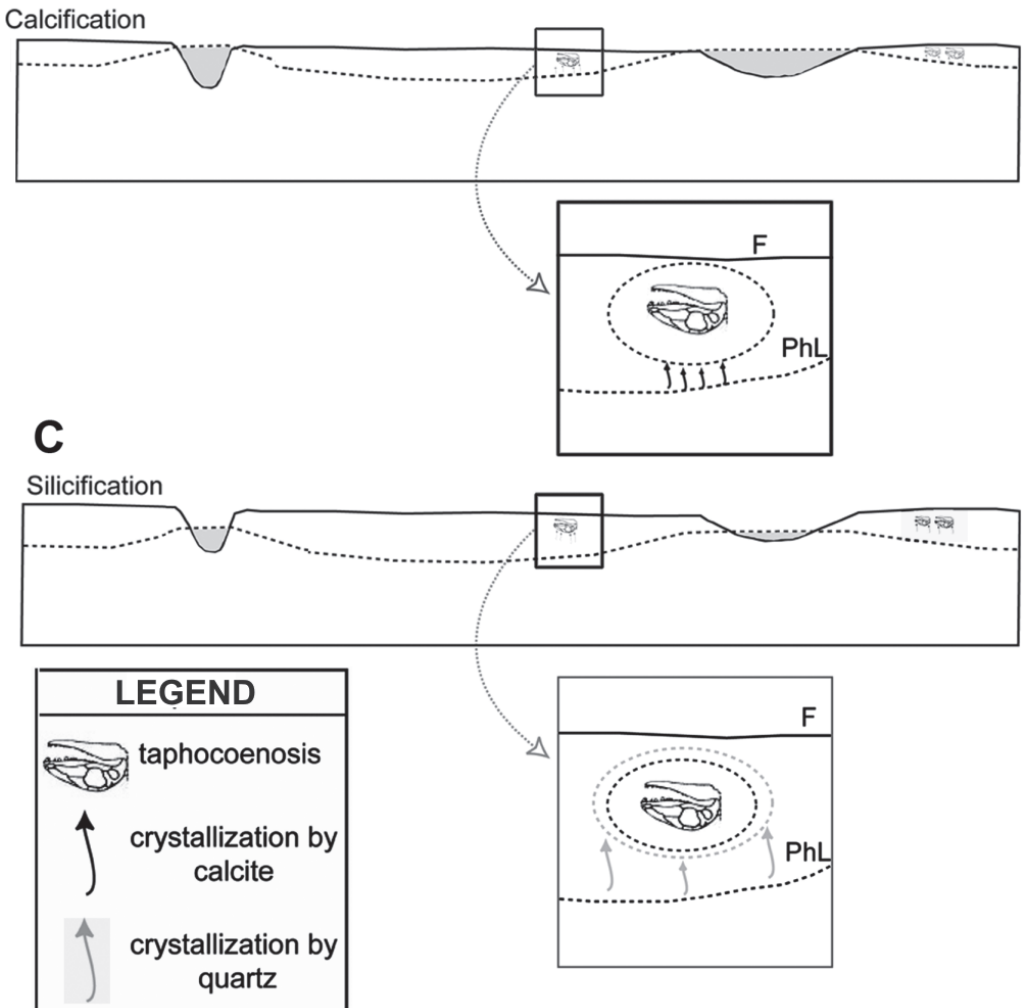

Figure 10. Taphonomic model as discussed in the text. A, reconstruction of the habitat, where the paleofauna would have occupied an ephemeral lake margin. The lake was sustained by the phreatic level and river channels. During overbank sedimentation, bones on the floodplain near the lake margin were buried and early diagenetic processes began. B, with the remains already buried and during high phreatic levels, the process of calcium deposition would have started. The calcium was carried by water raised up from the phreatic level by capillarity, which affected the bones that were in the vadose zone, forming the external concretions and permineralization observed in the collected specimens. C, in a drought period, the already carbonate encrusted bones suffered an incipient silicification because of the geochemical conditions surrounding the bones, since calcium carbonate creates an extremely alkaline microenvironment. This process probably occurred during early diagenesis. 
bones that were in the vadose zone, forming the external and internal concretions observed in the collected specimen.

During a subsequent drought period, the carbonate encrusted bones were subjected to incipient silicification, marking the early diagenetic phase of the diagenetic process. This silica probably precipitated in the carbonate encrusted bones because of the geochemically active halo surrounding the bones, since calcium carbonate creates an extremely alkaline microenvironment.

The absence of fossil bones and the small quantities of carbonate nodules and rhyzoliths in the lower portion of the mudstone section suggests a prolongated period of low phreatic level, representing a period of drought situation that resulted in formation of very low biomass during that period, hence the absence of fossils in that part of the stratigraphic section.

Finally, using an analogy with recent ecosystems, the locus represented by the Schoenstatt outcrop suggests an oasis, with availability of water and vegetation, occurring in the middle of a relatively extensive dry floodplain.

The Schoenstatt palaeoenvironment may be compared with Etosha pan in Namibia, an extensive topographic depression seasonally flooded, holding water for a short time during the rainy season. During the dry season the landscape changes. Large shallow lakes evaporate quickly and take the form of salt-crusted, desiccated mud. Because of these dramatic seasonal changes, species that reside here must be able to adapt or migrate to other areas (Hipondoka, 2005). The Etosha pan supports a great number of animals, such as white rhinos, elephants, hunting dogs, lions, leopards, and antelopes during the wet season (Mwalyosi, 1977). So, this area seems to have the function of a wetland in the semi-arid climate of Namibia, creating an oasis within the arid corridor which stretches from the northeast of the African continent to the coast of Namibia in the south-west (Bobe, 2006).

The Schoenstatt outcrop is interpreted as the geological record of a seasonally flooded pond, with huge concentration of calcium carbonate, located at a great semi-arid floodplain, similar in many ways to the present day environment of Ethosa pan in Namibia.

\section{CONCLUSIONS}

The taphonomic analysis presented here integrates sedimentological and paleontological data to explain the formation and preservation of a new type of taphocoenosis in South-Brazilian Triassic rocks. Based on this data set, can be concluded that the taphocoenosis had little or no direct influence of hydraulic transport, as indicated (i) by the enclosing rock types (finely laminated and massive mudstone of a distal floodplain setting) indicating slow settling of suspended sediment, incapable to transport bones, (ii) by the lack of orientation of the fossil bones and (iii) by the noticeable mixture of bones with very different sizes and densities.

The taphocoenosis contains mainly bones of herbivorous and carnivorous cynodonts $(90 \%)$ and hydraulic transportation appears to have played no role in its formation. Thus the faunal composition is taken to reflect the original biocoenosis, with a predominance of herbivores over carnivorous individuals. The attritional accumulation of bones discarded by the scavengers over multiple seasons led to a biogenic concentrated tanathocoenosis around the margins of a floodplain lake which was buried during periods of flooding and over bank sedimentation;

The variable distribution of carbonate nodules along the stratigraphic section of the Schoenstatt outcrop is indicative of oscillations of the phreatic level. The close association of root marks with nodules indicates periods of high water table. During those periods the area of the Schoenstatt outcrop was an ephemeral lake with abundant plant and animal life.

The Schoenstatt outcrop is representative of a humid environment within a huge floodplain subjected to semi-arid climatic conditions of the Middle Triassic. In this situation, the ephemeral lake margin developed vegetation and attracted herbivorous therapsids and, in their consequent carnivorous predator and scavenger species, an ecologic situation which resulted in a biased record, favoring the preservation and accumulation of the least nutritious bone elements.

\section{ACKNOWLEDGMENTS}

Thanks are due to R. Lyman and R. Smith for the critical review, which improved the manuscript; and W. Kalkreuth for helping us with the English version. Many thanks to C.L. Schultz for his great assistance during the early phase of development of the work. The authors acknowledge $\mathrm{CNPq}$ for financial support as a grant (MH, PQ 302666/04-4) and a scholarship (CBM).

\section{REFERENCES}

Abdala, F.; Ribeiro, A.M. \& Schultz, C.L. 2001. A rich cynodont fauna of Santa Cruz do Sul, Santa Maria Formation (middlelate Triassic), southern Brazil. Neues Jahrbuch für Geologie und Palaontologie, 11:669-687.

Andreis, R.R; Bossi, G.E. \& Montardo, D.K. 1980. O Grupo Rosário do Sul (Triássico) no Rio Grande do Sul-Brasil. In: CONGRESSO BRASILEIRO DE GEOLOGIA, 31, 1980. Anais, Balneário de Camboriú, SBG, 2:659-673.

Arcucci, A.B. 1990. Un nuevo Proterochampsidae (ReptiliaArchosauriformes) de la fauna local de los Chañares (Triásico Medio), La Rioja, Argentina. Ameghiniana, 27(3-4):364-378.

Bandyopadhyay, S.; Roychowdhury, T. K. \& Sengupta, D.P. 2002. Taphonomy of some Gondwana vertebrate assemblages of India. Sedimentary Geology, 147(1-2):219-245.

Beckner, J. R. \& Mozley, P.S. 1998. Origin and spatial distribution of early vadose and phreatic calcite cements in the Zia Formation, Albuquerque Basin, New Mexico, USA. International Association of Sedimentologists, Special Publication, 26:27-51.

Behrensmeyer, A.K. 1991. Terrestrial vertebrate accumulations. In: P.A. Allison \& D.E. Briggs (eds.) Taphonomy: releasing the data locked in the fossil record, Plenum, p. 291-335.

Behrensmeyer, A.K. \& Boaz, D.E.D. 1980. The recent bones of Amboseli National Park, Kenya, in relation to east African paleoecology. In: A.K. Behrensmeyer \& A. P.Hill (eds.) Fossils in the making: vertebrate taphonomy and paleoecology, The University of Chicago Press, p. 72-93.

Behrensmeyer, A.K \& Hook, R.W. 1992. Paleoenvironmental contexts and taphonomic modes. In: A.K. Behrensmeyer; J.D. Damuth; W.A. Dimichele; R. Potts; H.D. Sues \& S.L. Wing (eds.) Terrestrial 
ecosystems trough time, University of Chicago Press, p.15-136.

Bobe, R. 2006. The evolution of arid ecosystems in eastern Africa. Journal of Arid Environments, 66:564-584.

Bonaparte, J.F. 1971. Cerritosaurus binsfeldi Price, tipo de uma nova família de tecodontes (Pseudosuchia-Proterochampsia). Anais da Academia Brasileira de Ciências, 43(Supl.):417-422.

Davidson, I. \& Solomon, S. 1990. Was OH 7 the victim of a crocodile attack? In: S.Solomon; I. Davidson \& D. Watson (eds.) Problem solving in taphonomy: archaeological and palaeontological studies from Europe, Africa and Oceania. University of Queensland, p. 197-206.

Dominguez-Rodrigo, M. 1999. Flesh availability and bone modifications in carcasses consumed by lions: palaeoecological relevance in hominid foraging patterns. Palaeogeography, Palaeoclimatology, Palaeoecology, 149:373-388.

Fonseca, M.M. 1999. Caracterização faciológica das formações Santa Maria (Membro Alemoa) e Caturrita: interpretação da tipologia dos sistemas fluviais. Universidade Federal do Rio Grande do Sul, Master Dissertation, 132 p.

Hipondoka, M.H. 2005. The development and evolution of Etosha pan, Namibia. zur Universität Würzburg, Würzburg, Ph. D. Thesis, $162 \mathrm{p}$.

Holz, M. \& Barberena, M.C. 1994. Taphonomy of south Brazilian Triassic paleoherpetofauna: pattern of death, transport and burial. Palaeogeography, Palaeoclimatology, Palaeoecology, 107:179-197.

Holz, M. \& Scherer, C.M.S. 2000. Sedimentological and paleontological evidence of paleoclimate change during the South Brazilian Triassic: the register of a global trend towards a humid paleoclimate. Zentralblatt für Geologie und Paleontologie, 1(11-12):1589-1609.

Holz, M. \& Schultz, C.L. 1998. Taphonomy of the Brazilian Triassic paleoherpetofauna: fossilization mode and implications for morphological studies. Lethaia, 31:335-345.

Holz, M. \& Souto-Ribeiro, A. 2000. Taphonomy of the south Brazilian Triassic vertebrates. Revista Brasileira de Geociências, 30(3):491-494.

Hubert, J.F. 1978. Paleosol caliche in the New Haven Arkose, New Ark group, Connecticut. Palaeogeography, Palaeoclimatology, Palaeoecology, 24:151-168.

Hungerbühler, A. 1998. Taphonomy of the prosauropod dinosaur Sellurosaurus, and its implications for carnivore faunas and feeding habits in the Late Triassic. Palaeogeography, Palaeoclimatology, Palaeoecology, 143:1-29.

Klappa, C.F. 1980. Rhizolithes in terrestrial carbonates: classification, recognition, genesis and significance. Sedimentology, 27:613-629.

Machado, C.B. \& Kischlat, E-E. 2003. Novo registro de Rhadinosuchidae (Archosauriformes: Proterochampsia) para o Mesotriássico do Brasil. Paleontologia em Destaque, 44:48.

Mwalyosi, R.B.B. 1977. A count of large mammals in Lake Manyara National Park. East African Wildlife Journal, 15:333-335.

Njau, J.K. \& Blumenschine, R.J. 2006. A diagnosis of crocodile feeding traces on larger mammal bone, with fossil examples from the Plio-Pleistocene Odlvuai Basin, Tanzania. Journal of Human Evolution, 50:142-162.

Pierini, C.; Mizusaki, A.; Pimentel, N.; Faccini, U. \& Scherer, C. 2005. Paleoalterations in hydrocarbon reservoir rocks: the Sergi Formation case (Recôncavo Basin, NE Brazil). In: CONGRESSO DE P \& D EM PETRÓLEO E GÁS, 3, 2005. Resumos Expandidos, Salvador, Instituto Brasileiro de Petróleo e Gás, CD-ROM.

Reichel, M.; Schultz, C.L. \& Pereira, V.P. 2005. Diagenetic pattern of the vertebrate fossils from the Traversodontid Biozone, Santa
Maria Formation (middle Triassic of Rio Grande do Sul, southern Brazil). Revista Brasileira de Paleontologia, 8(3): 173-180.

Rogers, A.R. \& Broughton, J.M. 2001. Selective transport of animal parts by ancient hunters: a new statistical method and an application to the Emeryville Shellmound Fauna. Journal of Archaeological Science, 28:763-773.

Romer, A.S. 1971. The Chañares Triassic reptile fauna XI: two new long-snouted thecodonts, Chanaresuchus and Gualosuchus. Breviora, 379:1-22.

da Rosa, A.A.; Pimentel, N.L.V. \& Faccini, U.F. 2003. Paleoweathering, carbonate precipitation and vertebrate preservation in the alluvial deposits of the Middle to Upper Triassic of Santa Maria, RS, southern Brazil. In: LATINAMERICAN CONGRESS OF SEDIMENTOLOGY, 3, 2003. Abstracts Volume, Belém, p. 47-49.

Rubert, R.R. \& Schultz, C.L. 2004. Um novo horizonte de correlação para o Triássico Superior do Rio Grande do Sul. Pesquisas em Geociências, 31(1):71-88.

Sanders, W.J.; Trapani, J. \& Mitani, J.C. 2003. Taphonomic aspects of crowned hawk-eagle predation on monkeys. Journal of Human Evolution, 44:87-105.

Schultz, C.L. 1990. Os répteis fósseis da região de Santa Maria. Ciência \& Ambiente, 10:7-25.

Sill, W.D. 1995. Un nuevo Proterochampsidae de la Formación Ischigualasto, Triassico Superior, San Juan. p. 3. In: JORNADAS ARGENTINAS DE PALEONTOLOGIA DE VERTEBRADOS, 11, 1995. Resúmenes, Tucumán, p. 3.

Smith, R.M.H. 1980. The lithology, sedimentology and taphonomy of floodplain deposits of the Lower Beaufort (Adelaide Subgroup) Strata near Beaufort West. Transactions of the Geological Society of South Africa, 83:399-413.

Smith, R. M. H. 1993. Vertebrate taphonomy of late Permian foodplain deposits in the southwestern Karoo Basin of South Africa. Palaios, 8:45-67.

Smith, R.M.H \& Swart, R. 2002. Changing fluvial environments and vertebrate taphonomy in response to climatic drying in a mid-Triassic rift valley fill: the Omingonde Formation (Karoo Supergroup) of Central Namibia. Palaios, 17:249-267.

Souto, P.R.F. 2001. Tetrapod coprolites from the middle Triassic of southern Brasil. Gaia, 16:51-57.

Turnbull, W.D. \& Martill, D.M. 1988. Taphonomy and preservation of a monoespecific titanothere assemblage from the Washakie Formation (late Eocene), Southern Wyoming. An ecological accident in the fossil record. Palaeogeography, Palaeoclimatology, Palaeoecology, 63:91-108.

Voorhies, M.R. 1969. Taphonomy and population dynamics of an early Pliocene vertebrate fauna, Krox County, Nebraska. Contributions to Geology. Special Paper, 1:69.

Wood, J.M.; Thomas, R.G. \& Visser, J. 1988. Fluvial processes and vertebrate taphonomy: the upper Cretaceous Judith River formation, south-central dinosaur provincial park, Alberta, Canada. Paleogeography, Paleoclimatology, Paleoecology, 66:127-143.

Zerfass, H.; Chemale Jr., F.; Schultz, C.L. \& Lavina, E. 2004. Tectonics and sedimentation in southern South America during Triassic. Sedimentary Geology, 166:265-292.

Zerfass, E.; Lavina, E.L.; Schultz, C.L.; Garcia, A.J.V.; Faccini, U.F. \& Chemale, Jr, F. 2003. Sequence stratigraphy of continental Triassic strata of Southernmost Brazil: a contribution to southwestern Gondwana palaeogeography and palaeoclimate. Sedimentary Geology, 161(1-2):85-105.

Received in June, 2006; accepted in September, 2006 